\title{
A multiplex set for microsatellite typing and sexing of the European bee-eater (Merops apiaster)
}

\author{
Ghaniya $\mathrm{Bi}^{1}{ }^{1}$ Natalie dos Remedios ${ }^{1} \cdot$ Deborah A. Dawson ${ }^{1} \cdot$ Sjouke A. Kingma ${ }^{2}$. \\ Julia Schroeder $^{3,4}$ • Hannah L. Dugdale ${ }^{1,2,5}$
}

Received: 16 November 2015 /Revised: 5 April 2016/Accepted: 10 April 2016 /Published online: 7 May 2016

(C) The Author(s) 2016. This article is published with open access at Springerlink.com

\begin{abstract}
Microsatellite loci are widely used in ecological and evolutionary studies to assess inbreeding, genetic parentage and population structure. Such loci are often optimised in multiplexes to allow for economical and efficient use. Here, we tested 11 microsatellite loci designed for use in European bee-eaters (Merops apiaster), along with 31 loci isolated in other species, for their utility in European bee-eaters sampled on Susak Island, Croatia. Of these 42 loci, 20 were polymorphic in 38 individuals. These polymorphic loci were further assessed in a sub-set of 23 adults, excluding close relatives, and exhibited between three and 13 alleles each. All loci were autosomal, as indicated by the presence of heterozygotes in both males and females. One of the polymorphic loci exhibited low heterozygosity, three loci deviated from HardyWeinberg equilibrium and three pairs of loci displayed linkage disequilibrium. The remaining selected eight cross-species loci and seven loci isolated in European bee-eaters were combined with two sex-typing markers and optimised in five multiplexes. A combination of 15 autosomal loci of varying degrees of polymorphism makes this multiplex set particularly suitable for both parentage and spatial genetic analyses. This
\end{abstract}

Hannah L. Dugdale

h.dugdale@leeds.ac.uk

1 Department of Animal and Plant Sciences, University of Sheffield, Western Bank Sheffield S10 2TN, UK

2 Groningen Institute for Evolutionary Life Sciences, University of Groningen, PO Box 11103, 9700 CC Groningen, Netherlands

3 Department of Life Sciences, Imperial College London, Silwood Park Campus, Buckhurst Road, Ascot, Berks SL5 7PY, UK

4 Evolutionary Biology, Max Planck Institute for Ornithology, Eberhard Gwinner Strasse, 82319 Seewiesen, Germany

5 School of Biology, University of Leeds, Leeds LS2 9JT, UK multiplex set therefore provides a useful toolkit for studying kin selection and population genetics in the cooperatively breeding European bee-eater and, potentially, in other closely related species.

Keywords Cooperative breeding · Cross-species markers . European bee-eater $\cdot$ Merops apiaster $\cdot$ Microsatellite markers $\cdot$ Multiplex set

European bee-eaters (Merops apiaster) are a migratory bird species in the Meropidae family (order Coraciiformes). They breed in Southern Europe and the North of Africa and migrate to Southern Africa during winter (Fry 1984). Unlike many cooperatively breeding birds, European bee-eaters are a colonial species (Lessells et al. 1994). Colonies vary in size and can range from two up to several hundred breeding pairs (Fry 1984). Approximately $20 \%$ of broods in this species obtain help from other individuals that have failed in their breeding attempts (Lessells 1990). Females have greater natal dispersal distances than males, although breeding-site fidelity is very common (Lessells et al. 1994). However, less is known about intercolony dispersal (Dasmahapatra et al. 2004) and associated fine-scale genetic structure, features that may be important if we are to understand the evolution of various life-history traits such as cooperative breeding, coloniality and dispersal. Here, we characterise a set of polymorphic microsatellite loci, obtained via cross-species amplification, and combine these with existing European bee-eater loci (Dasmahapatra et al. 2004) and sexing markers (Dawson 2007) to create a powerful multiplex set. This multiplex set will facilitate the study of dispersal, parentage and kin selection in the European bee-eater and could potentially be of use in similar studies of closely related species.

A total of 42 microsatellite loci were tested for their utility in European bee-eaters, sampled on Susak Island, Croatia $\left(45^{\circ}\right.$ $29^{\prime} 26^{\prime \prime} \mathrm{N}, 14^{\circ} 19^{\prime} 46^{\prime \prime}$ E). Eleven of these loci were previously developed for the European bee-eater (Dasmahapatra et al. 


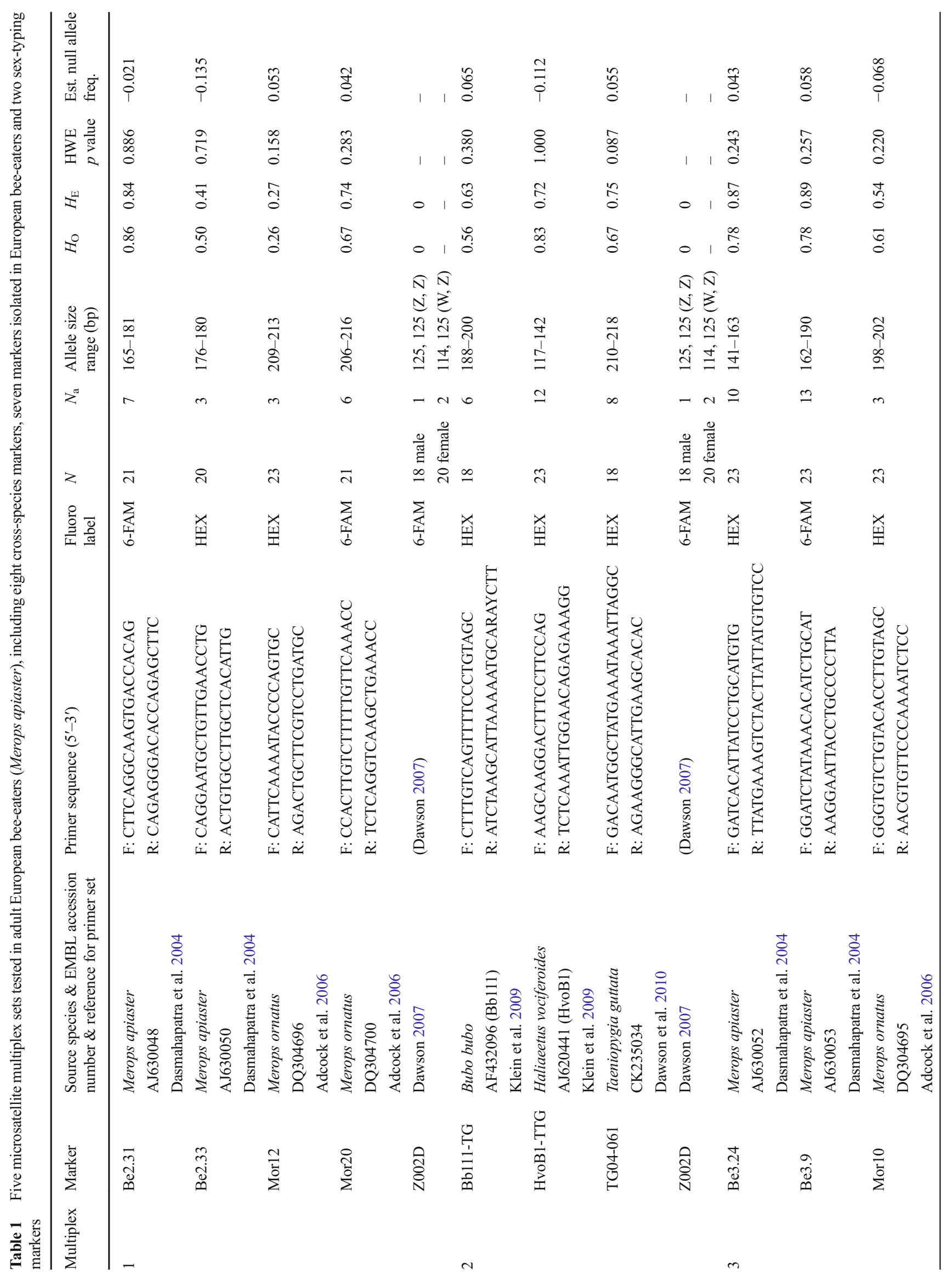




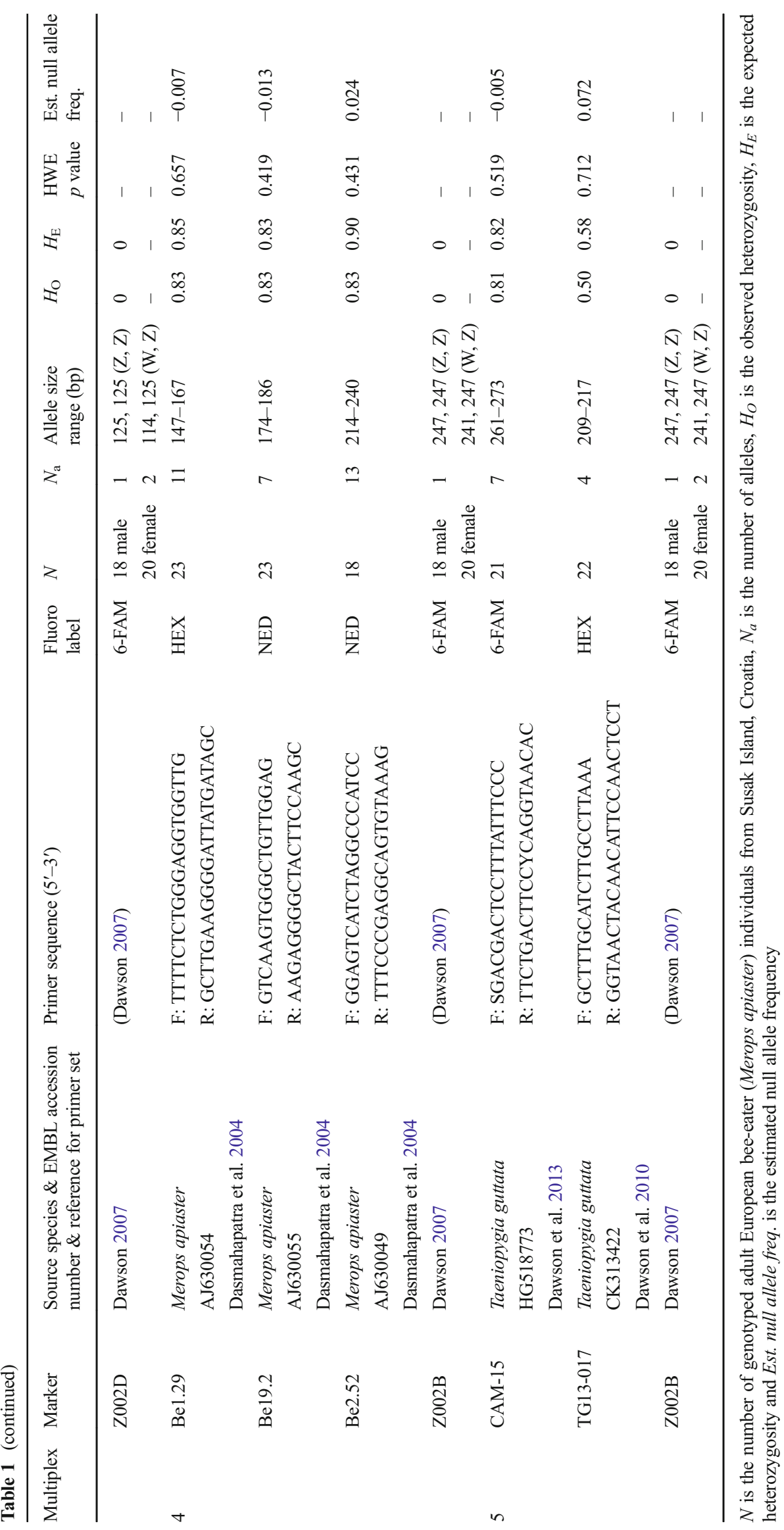


2004), and we assessed these loci for their utility in our study population. The remaining 31 loci were selected based on their high utility in multiple other species (Dawson et al. 2010, 2013), their utility in species belonging to the same order as European bee-eaters ( $N=7-23$; Appendix 1) or both. Five of these loci were originally isolated from the closely related Rainbow bee-eater (Merops ornatus; Adcock et al. 2006), and 26 were of high cross-species utility, including 24 that were previously characterised in a related but more distant Coraciiform species, the European roller (Coracias garrulous; Martín-Gálvez et al. 2014).

Blood samples (ca $50 \mu \mathrm{l}$ ) were collected by puncturing the brachial vein of 38 European bee-eaters from 15 colonies on Susak Island in 2014. These samples were stored in $1 \mathrm{ml}$ of $96 \%$ ethanol in rubber-sealed screw-topped microfuge tubes. We extracted genomic DNA via an ammonium acetate precipitation method (Nicholls et al. 2000) and performed PCR amplification in a $2-\mu \mathrm{l}$ volume. Each PCR reaction contained approximately $15 \mathrm{ng}$ of genomic DNA, $0.2 \mu \mathrm{M}$ of each primer (except

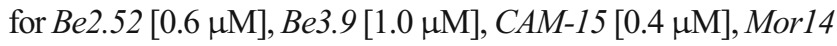
$[0.6 \mu \mathrm{M}]$ and TG13-017 [0.6 $\mu \mathrm{M}])$, HotStarTaq DNA polymerase, $\mathrm{MgCl}_{2}$ and dNTPs supplied at the concentrations stated in the manufacturer's buffer (QIAGEN Multiplex PCR Master Mix). Forward primers were fluorescently labelled and PCR products were amplified using a DNA Engine Tetrad PTC-225 Peltier thermal cycler (MJ Research).

Loci of high cross-species utility and those tested in the European roller were amplified in singleplexes across all 38 individuals with the following PCR profile: $95^{\circ} \mathrm{C}$ for $15 \mathrm{~min}$, followed by 35 cycles of $94{ }^{\circ} \mathrm{C}$ for $30 \mathrm{~s}, 56{ }^{\circ} \mathrm{C}$ for $90 \mathrm{~s}$ and $72{ }^{\circ} \mathrm{C}$ for $60 \mathrm{~s}$ and a final step of $60^{\circ} \mathrm{C}$ for $30 \mathrm{~min}$. The Rainbow and European bee-eater loci were initially assessed in multiplex reactions (designed using Multiplex Manager 1.2) in seven adults that were not close relatives $(R \leq 0.126$; GenAlEx 6.41 , Peakall and Smouse 2006) with the same PCR constituents, including $0.2 \mu \mathrm{M}$ of each primer (except for Be2.52 [0.6 $\mu \mathrm{M}]$, Be3.9 $[1.0 \mu \mathrm{M}]$ and Mor14 $[0.6 \mu \mathrm{M}]$ ), and the same PCR profile. PCR products were separated on an ABI 3730 DNA Analyser with an ABI ROX500 size standard and alleles scored using GENEMAPPER 3.7 (Applied Biosystems).

We found 20 loci to be polymorphic in seven to 38 individuals. Five loci were monomorphic and 17 failed to amplify a product (Appendix 1). The five monomorphic loci in this population may be variable and so of utility in other populations. Locus $B e 72$ is the same as Be3.9, which we tested under the latter name and found polymorphic (Adcock et al. 2006). Polymorphic loci were amplified as multiplex PCRs across all 38 individuals using the PCR profile stated above. Each multiplex set included a marker of known utility for sexing European bee-eaters; Z002B or Z002D (Dawson 2007). Loci were then characterised across a sub-set of 23 European bee-eaters, by selecting one male and one female adult from each colony to minimise overlapping generation and social structure effects. All
20 loci were autosomal as heterozygotes occurred in both sexes (18 males and 20 females assessed). One autosomal locus (TG01-000) amplified successfully in singleplex but failed to amplify in multiplex PCR (Appendix 1). Another locus (Be48) was polymorphic with only three alleles and little genetic variation in the Susak Island individuals $\left(H_{\mathrm{O}}=0.09\right.$, Appendix 1). Despite the relatively low variability among Susak Island individuals, this locus may be suitable for population structure analyses as heterozygosity was higher $\left(H_{\mathrm{O}}=0.29\right)$ in a French European bee-eater population (Dasmahapatra et al. 2004).

We used data from the 23 adult European bee-eaters to test each locus for deviation from Hardy-Weinberg Equilibrium (HWE) and for linkage disequilibrium among groups of loci (GENEPOP 4.2; Rousset 2008). Three loci (Be2.16, Morl4 and Mor15) deviated from HWE and were not included in the final multiplex set (Appendix 1). Loci Be2.16 and Mor15 also displayed high null allele frequency estimates $(>0.10$; CERVUS 3.0.03, Kalinowski et al. 2007). After correcting for multiple testing (Benjamini and Hochberg 1995), three pairs of loci (TG04-061 \& CAM-15, Mor10 \& Be19.2 and Mor10 \& $B b 111-T G)$ displayed linkage disequilibrium $(p<0.05)$. We therefore omitted data from CAM-15 and Mor 10 from the analyses of relatedness. The final 15 autosomal loci (eight crossspecies loci combined with seven loci isolated in European bee-eaters) were checked and confirmed unique using BLAST software (Altschul et al. 1997). These 15 loci, optimised in five multiplexes, will be useful in future studies, especially when combined with the two sex-typing markers (Table 1). In particular, the marker set will facilitate both fine-scale and large-scale population genetic structure analyses, and facilitate parentage assignment and relatedness estimation for kin selection studies. More specifically, this multiplex set will provide an efficient and economical method for investigating the social dynamics of European bee-eaters and, potentially, closely related species.

Acknowledgments Molecular work was carried out in the Molecular Ecology Laboratory at the University of Sheffield, UK. Simon Weigl and Liviu Parau assisted with sample collection. This work was carried out under licenses from the Croatian Ministry of Environmental and Nature Protection and the Croatian Institute for Ornithology.

\section{Compliance with ethical standards}

Funding GB was funded by a Genes and Development Summer Studentship (Genetics Society). DAD was funded by the Natural Environment Research Council (NERC), UK. HLD and NdR were funded by a NERC fellowship (NE/I021748/1). JS was funded by the Volkswagen Foundation. SAK was funded by a VENI-fellowship awarded by the Netherlands Organisation for Scientific Research (NWO 863.13.017). Fieldwork was funded by the Nicolaas Mulerius Foundation (University of Groningen) and by the Ecology Fund (Royal Netherlands Academy of Arts and Sciences; KNAW UPS/297/Eco/1414J).

Ethical approval All applicable international, national and/or institutional guidelines for the care and use of animals were followed.

This article does not contain any studies with human participants performed by any of the authors. 


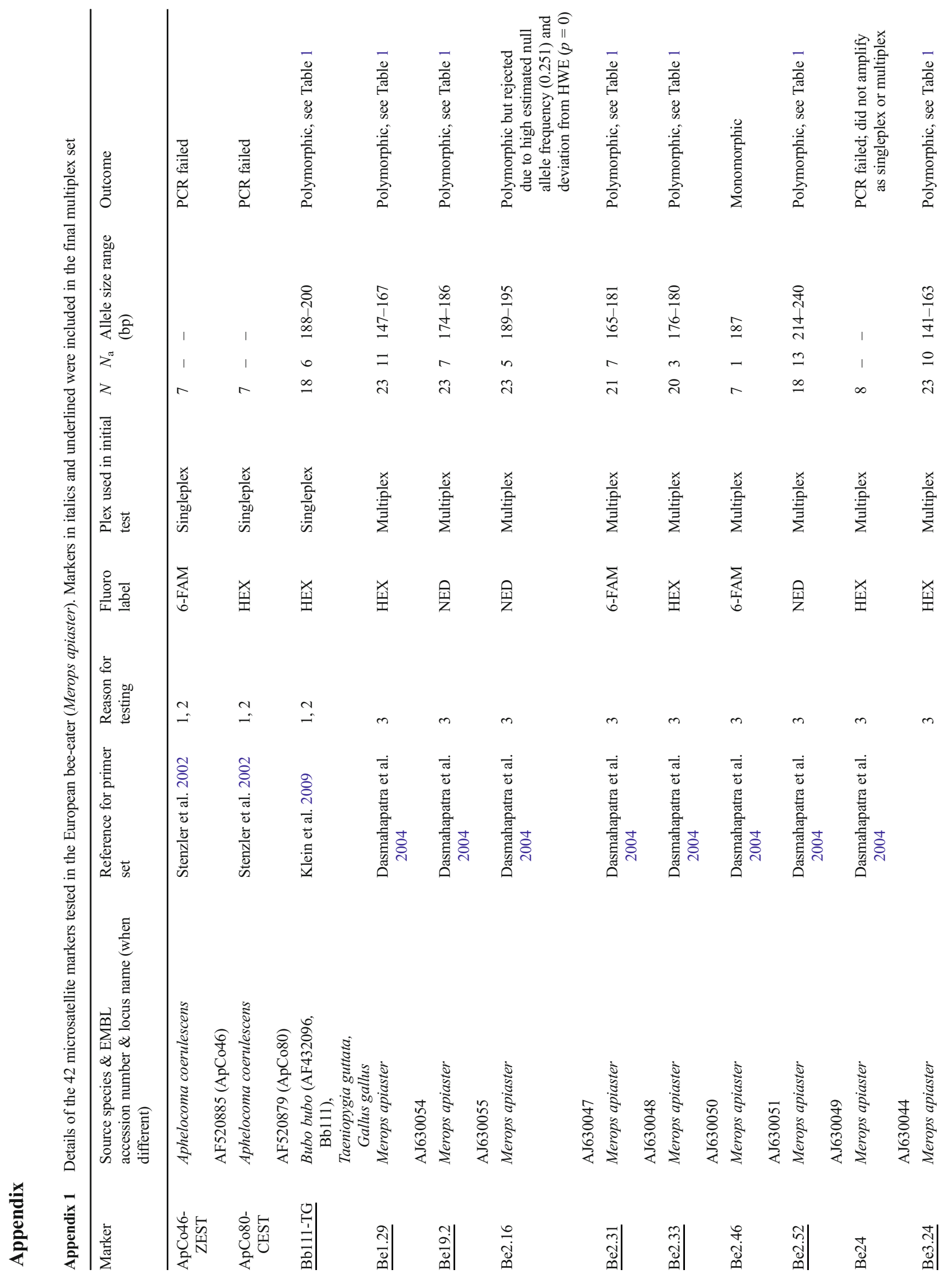




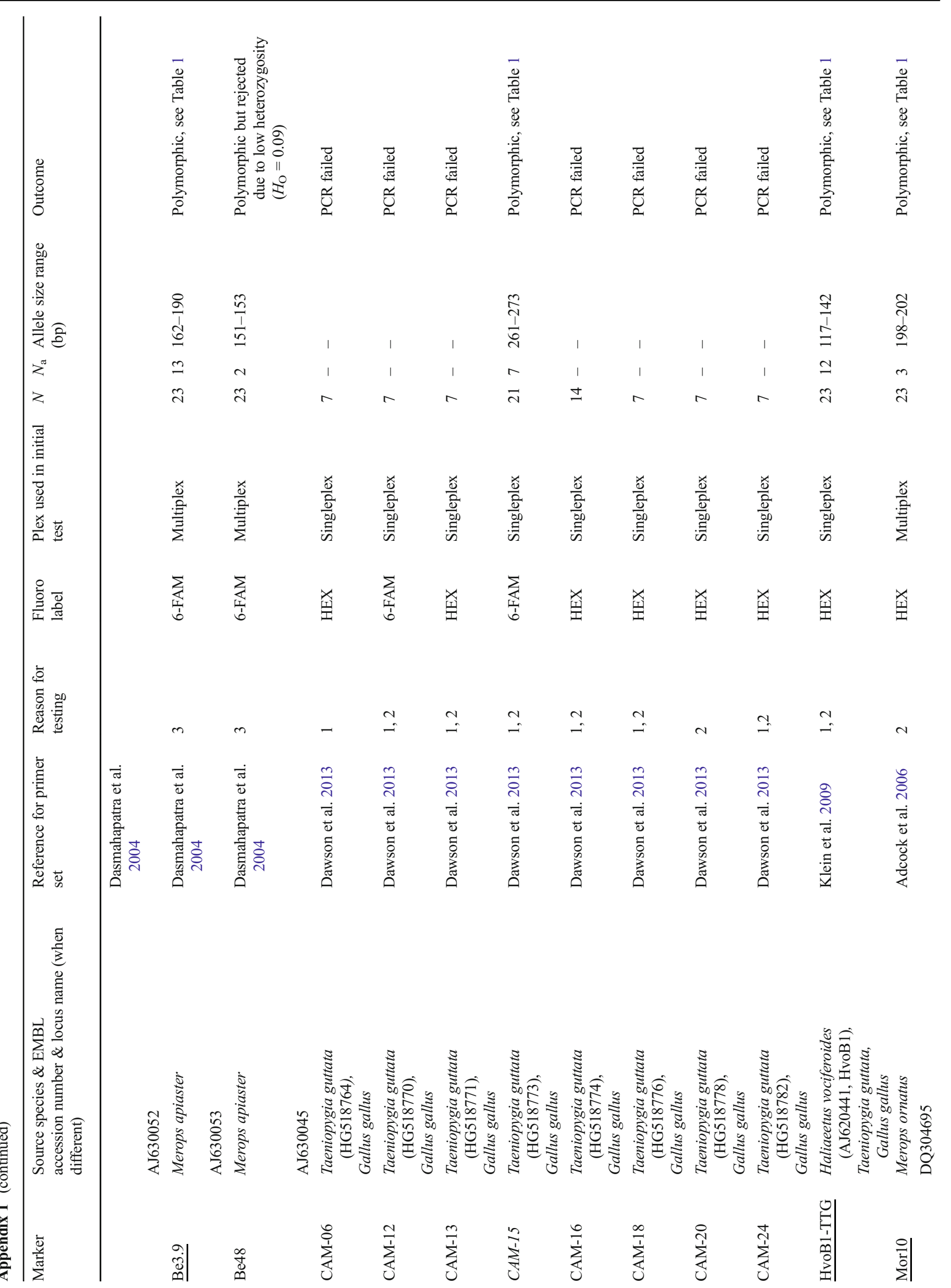




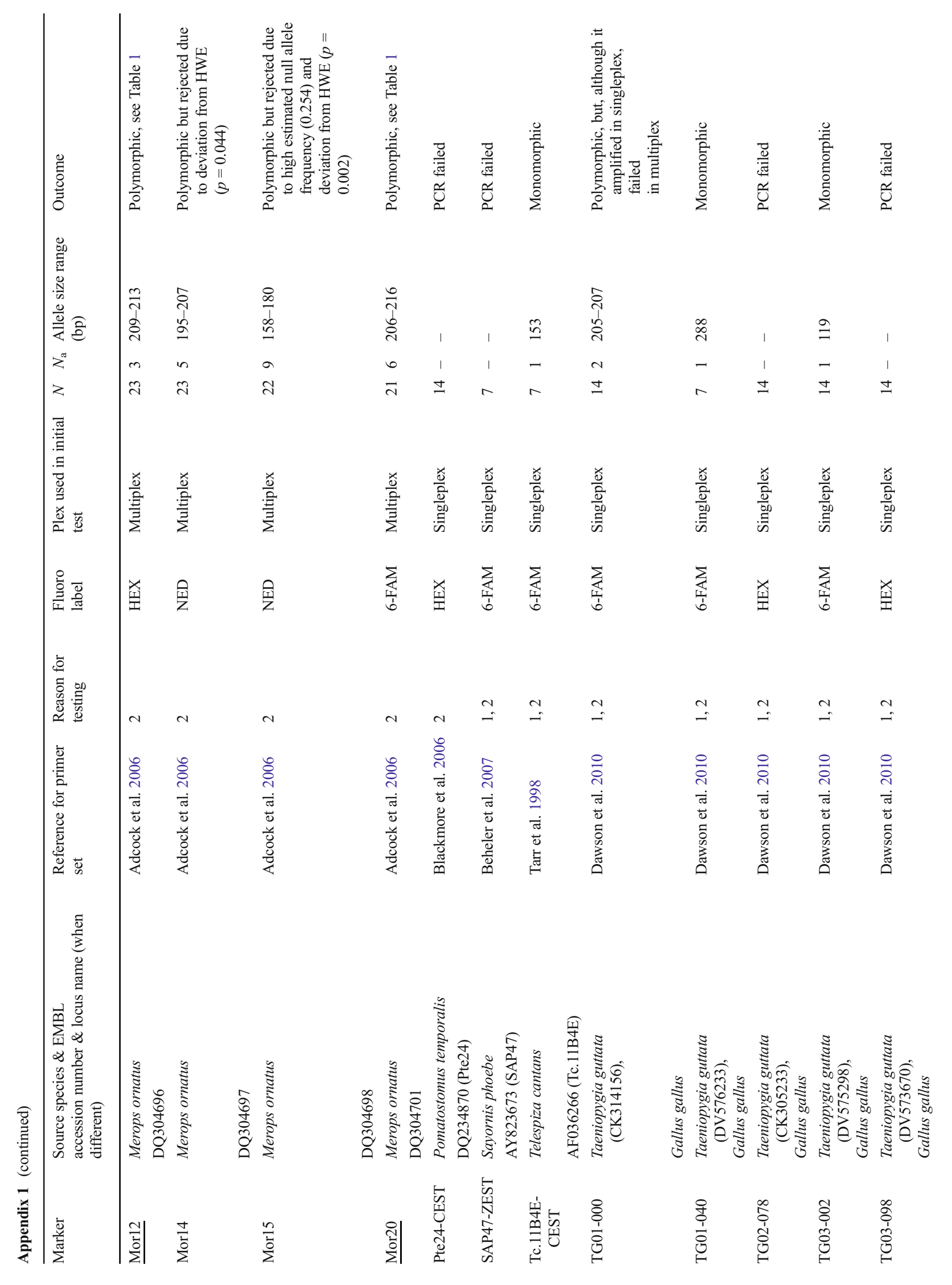




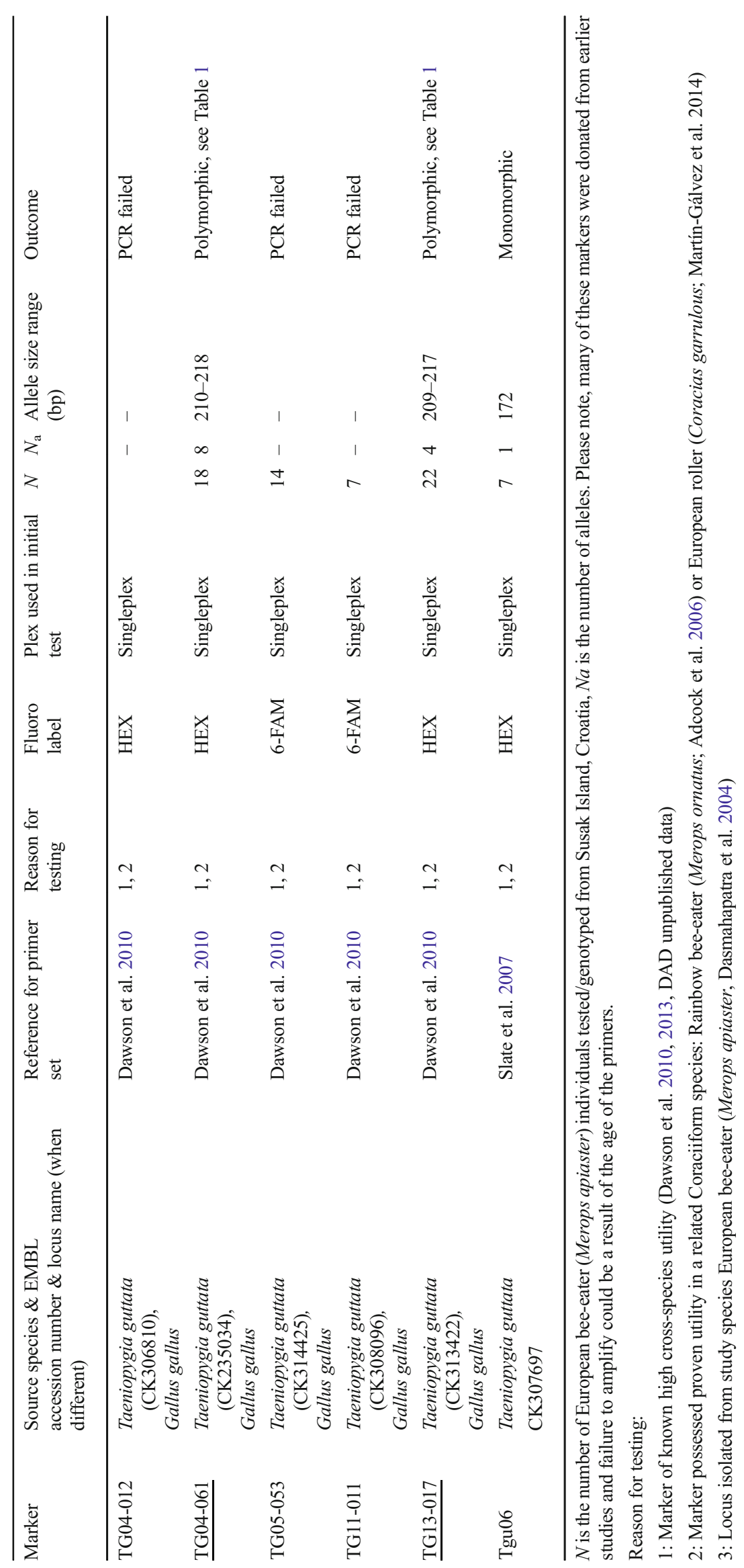


Open Access This article is distributed under the terms of the Creative Commons Attribution 4.0 International License (http:// creativecommons.org/licenses/by/4.0/), which permits unrestricted use, distribution, and reproduction in any medium, provided you give appropriate credit to the original author(s) and the source, provide a link to the Creative Commons license, and indicate if changes were made.

\section{References}

Adcock GJ, Hodges K, Boland CRJ, Cockburn A, Ebert D, Heinsohn R (2006) Microsatellite loci for behavioural studies of rainbow bee-eaters (Merops ornatus: Aves). Mol Ecol Notes 6:734-736

Altschul SF, Madden TL, Schäffer AA, Zhang J, Zhang Z, Miller W, Lipman DJ (1997) Gapped BLAST and psi-BLAST: a new generation of protein database search programs. Nucleic Acids Res 25:3389-3402

Beheler AS, Fike JA, Rhodes OE Jr (2007) Eight new polymorphic microsatellite loci from the eastern phoebe (Sayornis phoebe). Conserv Genet 8:1259-1261

Benjamini Y, Hochberg Y (1995) Controlling the false discovery rate: a practical and powerful approach to multiple testing. J R Stat Soc Ser B 57:289-300

Blackmore CJ, Adcock GJ, Ebert D, Heinsohn R (2006) Microsatellite loci for population and behavioural studies of grey-crowned babblers (Pomatostomus temporalis: Aves). Mol Ecol Notes 6:412-414

Dasmahapatra KK, Lessells CM, Mateman AC, Amos W (2004) Microsatellite loci in the European bee-eater, Merops apiaster. Mol Ecol Notes 4:500-502

Dawson DA (2007) Genomic analysis of passerine birds using conserved microsatellite loci. PhD Thesis, University of Sheffield, UK

Dawson DA, Horsburgh GJ, Küpper C, Stewart IRK, Ball AD, Durrant KL, Hansson B, Bacon I, Bird S, Klein Á, Lee J-W, Martín-Gálvez D, Simeoni M, Smith G, Spurgin LG, Burke T (2010) New methods to identify conserved microsatellite loci and develop primer sets of high utility — as demonstrated for birds. Mol Ecol Resour 10:475-494

Dawson DA, Ball AD, Spurgin LG, Martin-Galvez D, Stewart IR, Horsburgh GJ, Potter J, Molina-Morales M et al (2013) High- utility conserved avian microsatellite markers enable parentage and population studies across a wide range of species. BMC Genomics 14:176

Fry CH (1984) The bee-eaters. Buteo books. T \& A D Poyser, UK

Kalinowski ST, Taper ML, Marshall TC (2007) Revising how the computer program CERVUS accommodates genotyping error increases success in paternity assignment. Mol Ecol 16:1099-1106

Klein A, Horsburgh GJ, Küpper C, Major A, Lee PLM, Hoffmann G, Mátics R, Dawson DA (2009) Microsatellite markers characterized in the barn owl (Tyto alba) and of high utility in other owls (Strigiformes: AVES). Mol Ecol Resour 9:1512-1519

Lessells CM (1990) Helping at the nest in European bee-eaters: who helps and why? In: Population biology of passerine birds, an integrated approach, NATO ASI series. SpringerVerlag, Berlin, pp 357-368

Lessells CM, Avery MI, Krebs JR (1994) Nonrandom dispersal of kin: why do European bee-eater (Merops apiaster) brothers nest close together? Behav Ecol 5:105-113

Martín-Gálvez D, Molina-Morales M, Dawson DA, Parejo D, Martínez JG, Avilés JM (2014) Characterization of 28 microsatellite loci in the European roller Coracias garrulus (Coracidae, AVES). Eur J Wildl Res 60:843-850

Nicholls JA, Double MC, Rowell DM, Magrath RD (2000) The evolution of cooperative and pair breeding in thornbills Acanthiza (Pardalotidae). J Avian Biol 31:165-176

Peakall R, Smouse PE (2006) GENALEX 6: genetic analysis in Excel. Population genetic software for teaching and research. Mol Ecol Notes 6:288-295

Rousset F (2008) GENEPOP' 007: a complete re-implementation of the GENEPOP software for Windows and Linux. Mol Ecol Resour 8: 103-106

Slate J, Hale MC, Birkhead TR (2007) Simple sequence repeats in zebra finch (Taeniopygia guttata) expressed sequence tags: A new resource for evolutionary genetic studies of passerines. BMC Genomics 8:52

Stenzler LM, Fitzpatrick JW (2002) Isolation of microsatellite loci in the Florida Scrub-Jay Aphelocoma coerulescens. Mol Ecol Notes 2: $547-550$

Tarr CL, Conant S, Fleischer RC (1998) Founder events and variation at microsatellite loci in an insular passerine bird, the Laysan finch (Telespiza cantans). Mol Ecol 7:719-731 